\title{
MINI REVIEW ON THERAPEUTIC PROFILE OF PHENOXY ACIDS AND THIER DERIVATIVES
}

SHAHEEN BEGUM, BHARATHI K, PRASAD K. V. S. R. G.

Institute of Pharmaceutical Technology, Sri Padmavati Mahila Visvavidyalayam (Women's University), Tirupati 517502, Andhra Pradesh, India

Email: shaheen.pharmchem@gmail.com

Received: 24 Jan 2015 Revised and Accepted: 23 Aug 2016

\section{ABSTRACT}

Phenoxy acids and their derivatives are associated with a variety of biological activities such as antihyperlipidemic, hypoglycemic, antimicrobial, antiviral, antitubercular, anti-inflammatory, analgesic, antioxidant, anticancer and antihypertensive activities. This mini review outlines diverse biological properties of phenoxy acids and their derivatives.

Keywords: Phenoxy acids, Antitubercular, Antiinflammatory, Analgesic, Antioxidant

(C) 2016 The Authors. Published by Innovare Academic Sciences Pvt Ltd. This is an open access article under the CC BY license (http://creativecommons.org/licenses/by/4. 0/) DOI: http://dx.doi.org/10.22159/ijpps.2016v8i10.5005

\section{INTRODUCTION}

The phenoxy acetic acid moiety is present in diverse pharmacological agents such as hypolipidemic, analgesic, anti-inflammatory, antimycobacterial, antibacterial and antifungal agents.<smiles>[R]C(Oc1ccc[R]([H])c1)C(=O)O</smiles><smiles>[R][X]C(=O)C([R])OC1=CC=C[R1]C=C1</smiles>

$\mathrm{X}=\mathrm{O}, \mathrm{NH}$

$\mathrm{R}=\mathrm{H}, \mathrm{CH}_{3}, \mathrm{C}_{2} \mathrm{H}_{5}$

$\mathrm{R}_{1}=$ aryl or alkyl

General structure of phenoxy acids (i) phenoxy acid derivatives (ii)

\section{Hypolipidemic activity}

Fenofibrate (1) and gemfibrozil (2), clinically available hypolipidemic agents possess phenoxy propionic acid moiety in their structure and found to act as weak agonists of peroxisome proliferator-activated receptor alpha (PPAR- $\alpha$ ). Hyperlipidemia, characterized by increased blood cholesterol and triacylglycerol levels is considered as the principal risk factor for several lifethreatening cardiovascular diseases [1]. These drugs are highly effective in treating hyperlipidemia by increasing high-density lipoproteins (HDL) levels. Phenoxy acids and their derivatives containing various heterocyclic rings exhibited significant hypolipidemic activity in different animal models [2].

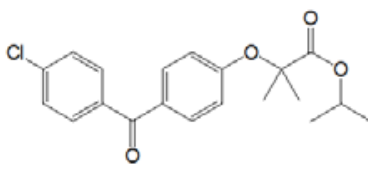

(1)

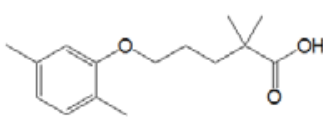

A novel series of phenoxy acetic acid derivatives (fig. 1) containing substituted aminothiazole ring were synthesized and screened for their hypolipidemic activity using high-fat diet induced hyperlipidemia in rats. The compounds were also investigated for their effects on body circumference and locomotor activity. The presence of aliphatic substitution on amino group resulted in significant increase in HDL level and locomotor activity, reduction in body weight and in body circumference whereas introduction of aromatic substitution decreased the activity [3].

\author{
$\mathrm{R}=\mathrm{CO}-\mathrm{CH}_{2}-\mathrm{CH}_{3}$ \\ $\mathrm{R}=\mathrm{CO}-\mathrm{CH}_{3}$ \\ $\mathrm{R}=\mathrm{CO}-\mathrm{C}_{6} \mathrm{H}_{5}$ \\ $\mathrm{R}=\mathrm{CO}-\mathrm{CH}_{2}-\mathrm{Cl}$ \\ $\mathrm{R}=\mathrm{CH}_{2}-\mathrm{C}_{6} \mathrm{H}_{5}$ \\ $\mathrm{R}=\mathrm{CH}_{2}-\mathrm{CO}-\mathrm{C}_{6} \mathrm{H}_{4} 4-\mathrm{Cl}$
}

Fig. 1

A novel series of 2-methyl-2-(substituted phenyl isoxazole) phenoxy acetic acid derivatives (fig. 2) were synthesized, and their hypolipidemic activity was evaluated by using triton induced hyperlipidemia in rats. Among the synthesized compounds, derivatives containing methoxy or methyl substituted phenyl ring and derivatives possessing chlorine atoms showed a significant decrease in the serum TG, LDL and VLDL (very low-density lipoproteins) levels along with an increase in serum HDL levels as compared to standard drug fenofibrate. Structure-activity relationship also demonstrated the importance of isoxazole ring for the activity [2].

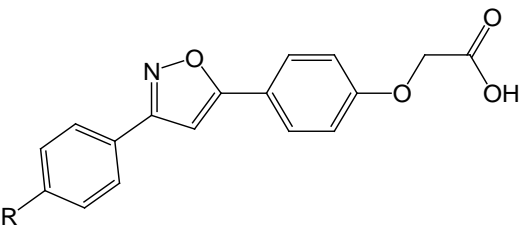

$\mathrm{R}=\mathrm{COCH}_{2} \mathrm{CH}_{3}, \mathrm{COCH}_{3}, \mathrm{COC}_{6} \mathrm{H}_{5}, 4-\mathrm{Cl}, \mathrm{CH}_{2} \mathrm{COC}_{6} \mathrm{H}_{5}$

Fig. 2

Li et al. synthesized novel phenoxy alkyl carboxylic acid derivatives (fig. 3) based on the natural scaffolds (flavonoids or resveratrol) and evaluated them for hypolipidemic activity using triton WR-1339induced hyperlipidemia and alloxan-induced diabetic models. Derivative bearing resveratrol scaffold lowered the triglyceride levels by $48.5 \%$, total cholesterol by $44.2 \%$ and was active comparable to that of the standard drug fenofibric acid in the tritoninduced hyperlipidemic model when administered orally at a dose of $300 \mathrm{mg} / \mathrm{kg}$ body weight. This derivative significantly lowered triglycerides levels in an alloxan-induced diabetic model upon oral administration at a dose of $150 \mathrm{mg} / \mathrm{kg}$ body weight. Molecular 
docking studies revealed that the most active compound can bind well with the target enzyme PPAR- $\alpha$ [4].

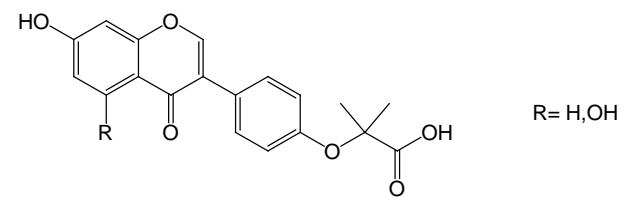

Fig. 3

\section{Antinociceptive and Antiinflammatory activity}

A series of novel phenoxy acid hydrazide derivatives containing carboxylic moiety such as 4-oxobutanoic acid at $4^{\text {th }}$ position (fig. 4) were synthesized, and their antinociceptive, and anti-inflammatory activities were evaluated. Most of the derivatives were found to exhibit peripheral nociceptive effects. The results demonstrated that the presence of acidic moiety increased the peripheral antinociceptive activity and reduced the central antinociceptive activity [5].

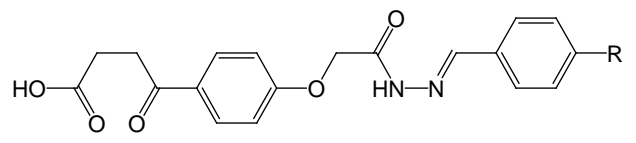

$\mathrm{R}=\mathrm{H}, \mathrm{C}, \mathrm{CH}_{3}, \mathrm{OCH}_{3}, \mathrm{NO}_{2}, \mathrm{CN}, \mathrm{N}\left(\mathrm{CH}_{3}\right)_{2}, \mathrm{CH}\left(\mathrm{CH}_{3}\right)_{2}, \mathrm{OH}$

Fig. 4

Gheraldini et al. synthesized phenoxy ester derivatives containing Nmethylpropane ring such as SM 21, (3- $\alpha$-tropanyl 2-[4-Cl-phenoxy] butyrate and PG-9, $\alpha$-tropanyl 2-(4-bromophenyl) propionate (fig. 5) keeping in view that atropine induces central antinociception by increasing cholinergic transmission. These derivatives were evaluated for their central and peripheral analgesic activities in different animal models and nootropic properties. Both the compounds showed promising analgesic activities and also exhibited nootropic activities $[6,7]$.<smiles>CC(Oc1ccc(Cl)cc1)C(=O)OC/C=C\C(=O)N(C)C</smiles>

SM 21

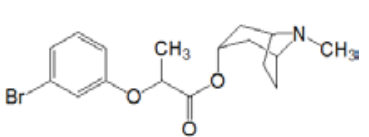

PG-9
Fig. 5

A novel series of 2-(substituted phenoxy)-N-(1-phenylethyl) acetamide derivatives (fig. 6) were synthesized using 1phenylethylamine and substituted phenols. The synthesized amides were evaluated for their anticancer activity against MCF-7 (breast cancer), SK-N-SH (neuroblastoma), anti-inflammatory activity and analgesic activity. The results showed that halogen-containing derivatives increased the anticancer and anti-inflammatory activity whereas nitro group bearing derivatives exhibited good anticancer, antiinflammatory and analgesic activities [8].<smiles>[R]c1ccc(OCC(=O)NC(C)c2ccc(Cl)cc2)cc1</smiles>

$\mathrm{R}=4-\mathrm{Cl},-\mathrm{NO}_{2},-\mathrm{OCH}_{3},-\mathrm{CH}_{3}$

Fig. 6
Bhavna et al. synthesized phenoxy ester and amide derivatives (fig. 7) using paracetamol. The synthesized compounds showed promising analgesic and antipyretic activities comparable to the standard drug paracetamol [9].<smiles>CC(=O)Nc1ccc(OCC(=O)Nc2ccc(S(N)(=O)=O)cc2)cc1</smiles><smiles>CCn1cc(C(=O)O)c(=O)c2ccc(F)c(N3CCN(C(=O)COc4ccc(NC(C)=O)cc4)CC3)c21</smiles>

Fig. 7

\section{Hypoglycemic activity}

Nikalje et al. synthesized a series of novel phenoxy amide derivatives possessing 2, 4-thiazolidinedione moiety (fig. 8) by mixing 2, 4-thiazolidinedione and 2-(4-formyl phenoxy) $\mathrm{N}$ substituted acetamide at room temperature. The synthesized compounds were evaluated for their hypoglycemic activity in mice model and the results showed that several derivatives bearing electron-releasing substituents such as methyl or methoxy groups exhibited promising hypoglycemic activity [10].<smiles>O=C(COc1ccc(/C=C2/SC(=O)NC2=O)cc1)N[Ge]</smiles>

$$
\begin{aligned}
\mathrm{Ar}= & \mathrm{C}_{6} \mathrm{H}_{5}, 2-\mathrm{Cl}-\mathrm{C}_{6} \mathrm{H}_{4}, 4-\mathrm{OH}-\mathrm{C}_{6} \mathrm{H}_{4}, 4-\mathrm{NO}_{2}-\mathrm{C}_{6} \mathrm{H}_{4}, 4-\mathrm{CH}_{3}-\mathrm{C}_{6} \mathrm{H}_{4}, \\
& 4-\mathrm{OCH}_{3}-\mathrm{C}_{6} \mathrm{H}_{5}, 2-\mathrm{OH}-\mathrm{C}_{6} \mathrm{H}_{4}
\end{aligned}
$$

Fig. 8

The same research group further synthesized a series of derivatives using 2-methoxyphenoxy-N-substituted acetamide (fig. 9) and reported significant hypoglycemic activity with all the derivatives. Good activity was observed with derivatives containing electron releasing methoxy group on phenyl ring bearing phenoxy acid scaffold [11].

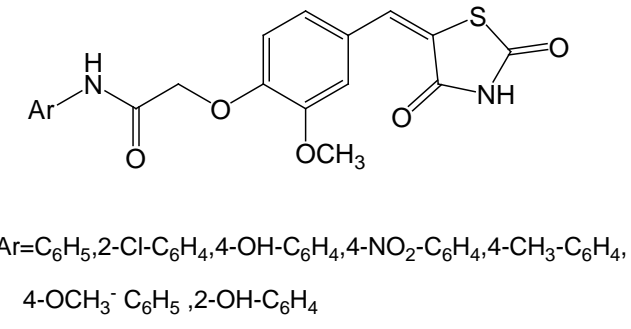

Fig. 9

\section{Anticancer and antiviral activity}

Shahar Yar et al. synthesized substituted phenoxy acetic acid derived pyrazolines (Fig.10) by the reaction between 2-\{4-[3- $(2,4-$ dihydroxyphenyl)-3-oxo-1-propenyl]-2-methoxyphenoxy\} acetic acid and various acid hydrazides and screened them for their in vitro cytotoxicity and antiviral activity. 


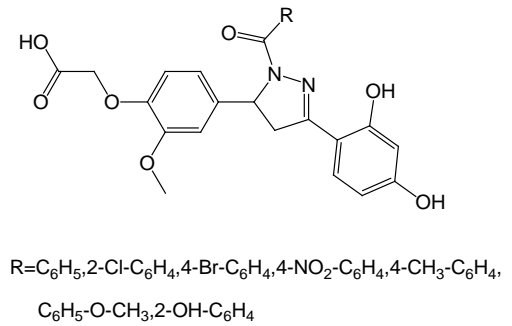

Fig. 10

The highest cytotoxic activity was observed with 2-hydroxy phenyl derivative against human embryonic lung (HEL) cells, at a minimum cytotoxic concentration (MIC) of $0.16 \mu \mathrm{g} / \mathrm{ml}$. The results showed that most of the derivatives have good cytotoxic activity but poor antiviral activity [12].

Vinayak et al. synthesized novel phenoxy acetamide derivatives (fig. 11) where amide nitrogen is substituted with the heterocyclic ring and evaluated these compounds for MTT (Tetrazolium dye) assay using various cell lines such as HepG2 (human liver cancer cell line) and Caco-2 (human colonic epithelial cell line). Among the synthesized compounds, derivative bearing fluoro substitution at $2^{\text {nd }}$ position was found to be highly active on $\mathrm{Caco}-2$ cell line with $\mathrm{IC}_{50}$ of $1.8 \mu \mathrm{mol}$ whereas other compounds showed less cytotoxicity on all the three cell lines as compared with the standard drug 5-fluoro uracil [13].<smiles>[R]c1ccc(OCC(=O)Nc2nnc(-c3cccnc3-c3ccc(OC)cc3)s2)cc1</smiles>

$\mathrm{R}=4-\mathrm{Cl}, 4-\mathrm{OCH}_{3}, 4-$ phenoxy,4- $\mathrm{F}, 2-\mathrm{F}$

Fig. 11

A series of phenoxy acetamide derivatives (fig. 12) were synthesized containing adamantyl or substituted phenyl or thiophene ring at $4^{\text {th }}$ position of phenoxy acetic acid. The synthesized derivatives were evaluated for their inhibitory activity on HIF-1R (hypoxia-inducible factor-1) protein accumulation and its target gene expression under hypoxic conditions in human hepatocellular carcinoma (Hep3B) cells [14].<smiles>[R]c1ccc(OCC(=O)Nc2ccccc2C(=O)O)cc1</smiles>
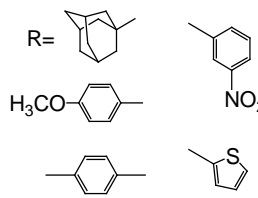

Fig. 12

\section{Antitubercular activity}

A series of novel is substituted pyrazolo phenoxy acetic acid derivatives (fig. 13) were synthesized and evaluated them for antitubercular activity using Middle brook 7 49 agar medium against $\mathrm{H}_{37} \mathrm{Rv}$ Strain of M. tuberculosis. Most of the synthesized derivatives displayed significant antitubercular activity [15].<smiles>[R1]CC1C(c2ccc([R])cc2)=NN=C1c1ccc(OCC(=O)O)cc1</smiles>

$\mathrm{R}=-\mathrm{H}, \mathrm{Cl}, \mathrm{OCH}_{3}, \mathrm{OH}$

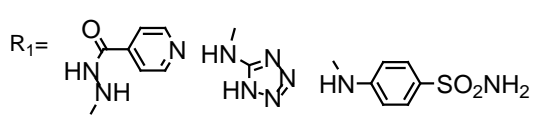

Fig. 13

A novel series of 3-Fluoro-4-nitrophenoxy acetamide derivatives (fig. 14) were synthesized and assessed for their antitubercular activities using microdilution method. All the derivatives exerted moderate to good activity against $M$. tuberculosis $\mathrm{H} 37 \mathrm{Rv}$ and derivative containing nitro group at $3^{\text {rd }}$ position was found to be the most promising derivative in the series, which showed MIC value of $4 \mu \mathrm{g} / \mathrm{ml}$ for both $\mathrm{H} 37 \mathrm{Rv}$ strain of M. tuberculosis and rifampinresistant M. tuberculosis 26 [16].<smiles>[R]c1cccc(NC(=O)COc2ccc([N+](=O)[O-])c(F)c2)c1</smiles>

$\mathrm{R}=3-\mathrm{Cl}, 3,4-\mathrm{Cl}_{2}, 3-\mathrm{NO}_{2}, 3-\mathrm{CF}_{3}, 2-\mathrm{CN}$

Fig. 14

\section{Antibacterial and antifungal activity}

A series of new peptides containing isopropyl and methyl substituted phenoxy amide moiety (fig. 15) has been synthesized by treating the 2-(2'-isopropyl-5'-methylphenoxy) acetic acid with amino acid methyl esters or dipeptides. Antibacterial and antifungal activities were evaluated for the synthetic peptides against Pseudomonas aeruginosa and Staphylococcus aureus pathogenic Candida albicans [17].

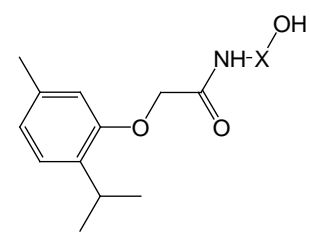

X=L-Phe,L-Val,L-Ile,L-Try,L-Pro-L-Pro,L-Ala-L-Leu

Fig. 15

A series of azomethine derivatives of phenoxy acetic acid(fig. 16) were synthesized by treating 2-formylphenoxyacetic acid with aromatic amines such as 2,4-dimethylpyridine and 2,3-dichloro aniline. These compounds were assayed by the disc diffusion method for antibacterial activity using several bacteria such as Staphylococcus aureus and Escherichia coli.

Among the derivatives tested, p-amino acetanilide, 2, 3-dichloro aniline and p-toluidine containing derivatives exhibited good antibacterial activity, similar to that of standard drug ciprofloxacin [18]. 
<smiles>[R]N=Cc1ccccc1OCC(=O)O</smiles>

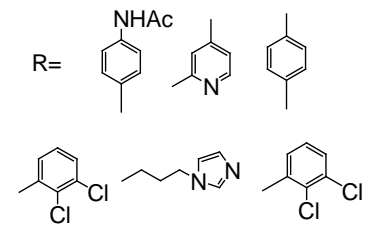

Fig. 16

Kaplancikli et al. synthesized a series of phenoxy acetamide derivatives substituted with carbazole moiety (fig. 17) by treating phenoxy acetamide with various ring-substituted phenols. These compounds were screened for their antibacterial and antifungal activities against Micrococcus luteus, Bacillus subtilis, Staphylococcus aureus, Listeria monocytogenes and Candida albicans.

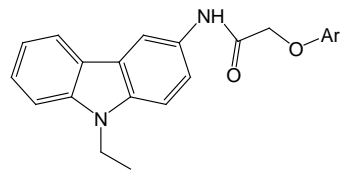

$\mathrm{Ar}=2,4\left(\mathrm{CH}_{3}\right)_{2}, 2-\mathrm{Cl}-\mathrm{C}_{6} \mathrm{H}_{5}, 2-\mathrm{NO}_{2}-\mathrm{C}_{6} \mathrm{H}_{5}, 2-\mathrm{CH}_{3}, 2-\mathrm{C}_{2} \mathrm{H}_{5}$, Quinolin -8-yl

Fig. 17

These compounds showed notable antimicrobial activity against the tested organisms. The compounds were also studied for their cytotoxic effects using MTT assay, where quinoline bearing derivative had the poor cytotoxic activity against NIH 3T3 (the murine fibroblast) cells [19].

\section{MDR (Multidrug resistance) reversing activity}

P-glycoprotein (Pgp) can actively transport anticancer agents out of the cancer cells and decrease their intracellular accumulation. Pgp has emerged as a promising target for cancer therapy and in the development reversal agents to overcome Pgp-mediated MDR. Adamantyl based Pgp inhibitor (fig. 18) is highly potent which has phenoxy acetamide unit in its structure.

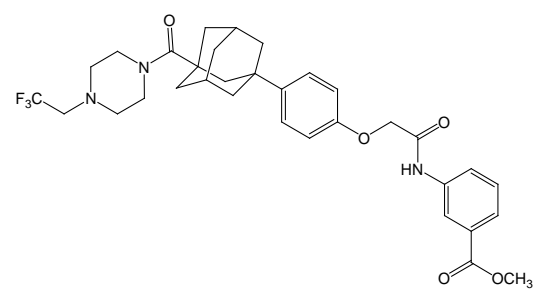

Fig. 18

Lee et al. synthesized a series of phenoxy- $\mathrm{N}$-phenylacetamide derivatives (fig. 19) and tested for their ability to inhibit Pgp, using a Pgp over-expressing breast cancer cell lines (MCF-7/ADR). Derivative with methyl furyl substitution showed a 3-fold increased inhibition compared with verapamil, a potent Pgp inhibitor, whereas rest of the compounds exhibited moderate activity [20].

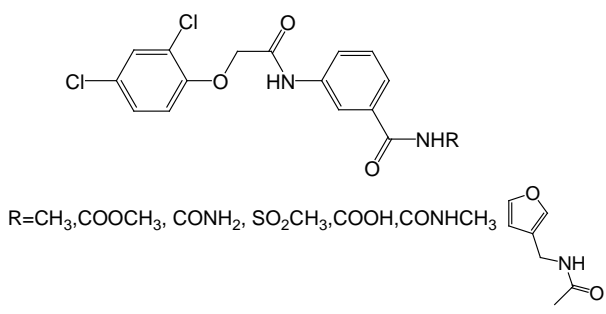

Fig. 19

\section{Cholecystokinin-B receptor antagonistic activity}

Takeda et al. synthesized various phenoxy acetamide derivatives (fig. 20) and evaluated them for their cholecystokinin-B receptor antagonistic activity. Most of the derivatives exhibited good affinity for these receptors, and structure-activity relationship showed the importance of the optimal size of the $N$-alkyl chains for the inhibitory activity. Derivatives bearing cyclohexyl ring or methyl pentyl side chain demonstrated the highest activity [21].

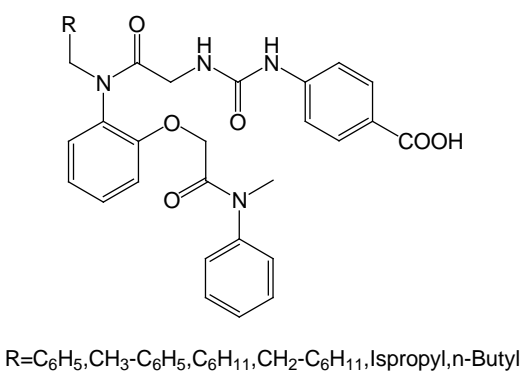

Fig. 20

\section{Antihypertensive activity}

Various phenoxy acetamide derivatives containing pyridazine heterocyclic ring at para position (fig. 21) were synthesized, and their antihypertensive effects were evaluated using in vitro method using standard reference drug hydralazine. Derivative having pyrrolidine ring on amide nitrogen showed moderate antihypertensive activity whereas introduction of other heterocyclic rings such as piperidine, morpholine, phenyl hydrazine and aniline significantly reduced the antihypertensive activity [22].

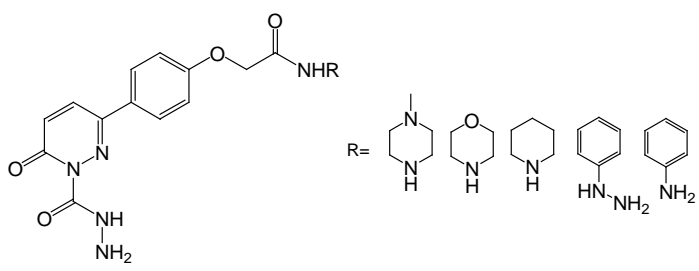

Fig. 21

\section{Antioxidant activity}

Prashanth et al. synthesized a series of (4-benzoyl-phenoxy)-acetic acid derivatives (fig. 22) and tested in vitro antioxidant effects by using 1, 1-diphenyl-1-picrylhydrazyl (DPPH), nitric oxide (NO) and hydrogen peroxide $\left(\mathrm{H}_{2} \mathrm{O}_{2}\right)$ radical scavenging assays. Among the synthesized compounds, unsubstituted derivative and derivative possessing chlorine atom on benzoyl ring showed good radical scavenging activity in all the three methods compared to the standard drug ascorbic acid. Derivative containing methoxy substituent on benzoyl ring showed good antioxidant activity only in hydrogen peroxide method and rest of the compounds showed moderate to poor radical scavenging activity [23].<smiles>[R]c1ccc(C(=O)c2cc([R2])c(OCC(=O)O)c([R])c2)c([R])c1</smiles>

$$
\begin{aligned}
& \mathrm{R}_{1}=\mathrm{Br},-\mathrm{CH}_{3} \\
& \mathrm{R}_{2}=\mathrm{H},-\mathrm{CH}_{3} \\
& \mathrm{R}_{3}=\mathrm{H},-\mathrm{Cl} \\
& \mathrm{R}_{4}=\mathrm{H},-\mathrm{F},-\mathrm{Br}, \mathrm{CH}_{3}, \mathrm{OCH}_{3}
\end{aligned}
$$


A novel series of phenoxy acids containing chalcone scaffold (fig. 23) were synthesized and screened for their antioxidant activity using DPPH free radical scavenging assay. All the synthesized compounds were found to display good activity in this assay indicating that these structures are potential antioxidant agents [24].<smiles>[R1]C1CCCc2cc(O)c(/C=C/C(=O)c3ccc(OCC(=O)O)cc3)cc21</smiles>

$$
\begin{aligned}
\mathrm{R} 1 & =5-\mathrm{CH} 3,7-\mathrm{CH} 3,8-\mathrm{CH} 3 \\
& =7-\mathrm{OCH} 3,8-\mathrm{OCH} 3 \\
& =5,8-(\mathrm{CH} 3) 2
\end{aligned}
$$

Fig. 23

\section{Miscellaneous activities}

Phenoxy acid containing chemical compounds are versatile for their herbicidal properties. Several selective herbicides such as 2, 4Dichloro phenoxy acetic acid (3), Clomeprop (4) and Difenopenten (5) contain phenoxy acid moiety as a part of their structure [25].

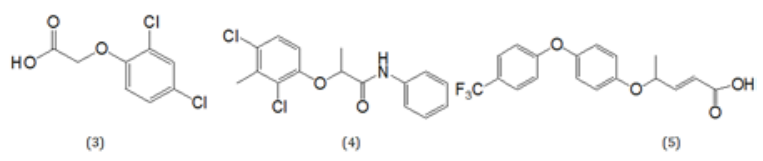

A series of phenoxy acetamide derivatives possessing substituted heterocyclic moiety (fig. 23) were synthesized using tetrabutylammonium bromide as phase transfer catalyst from corresponding o-fluorophenol and evaluated for their herbicidal activities. The preliminary herbicidal tests showed that the synthesized compounds have good inhibitory activities against root and stalk of dicotyledon plants [26].

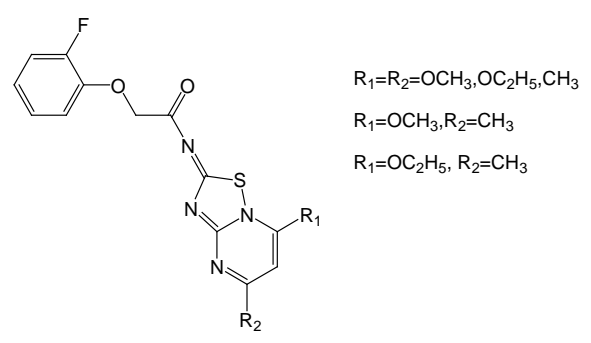

Fig. 24

A novel series of phenoxy isobutyric acid derivatives (fig. 24) in the form of choline salt were synthesized which were observed to have photostability and better reactivity [27]

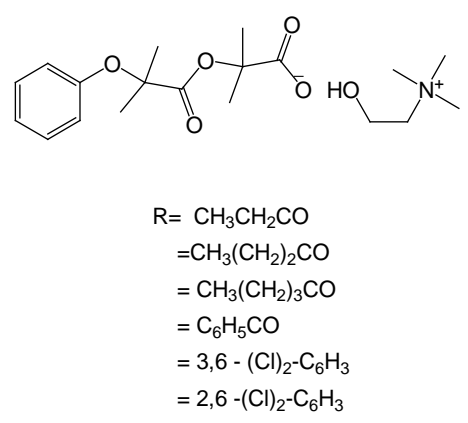

Fig. 25
Salicylamidoacetic acid hydrazide (6) was found to have good analgesic and antiinflammatory properties and fewer side effects. A series of phenoxy hydrazide derivatives (fig. 25) were synthesized to obtain safe and effective agents [28].<smiles>NNC(=O)CNC(=O)c1ccccc1O</smiles>

(6)<smiles></smiles>

Fig. 26

PPAR- $\gamma$ (Peroxisome proliferated activated receptor-gamma), class of proteins, have been identified as valid targets for type II diabetes [2931]. Clinically available drugs such as glitazones exhibit good affinity for these target structures. Several $\alpha$-phenoxy propionic acid derivatives (fig. 26) were designed and molecular docking studies were performed to determine their affinity for PPAR- $\gamma$ structure. The studied ligands demonstrated a good affinity for the protein [32].

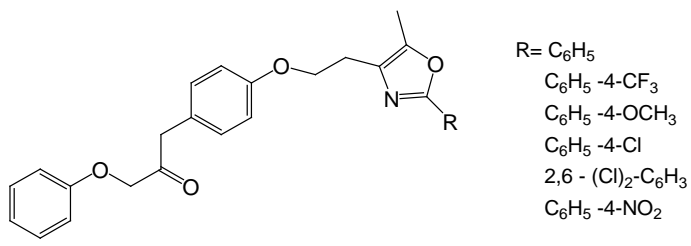

Fig. 27

A novel series of phenoxy containing amide linker and various substituted heterocyclic rings such as pyrazole (fig. 28) were synthesized and evaluated for their PPAR- $\gamma$ inhibitory activity. Most of the derivatives displayed good activity and derivative possessing methyl functionality at $3^{\text {rd }}$ position displayed the highest activity in the in vitro and in vivo models [33].

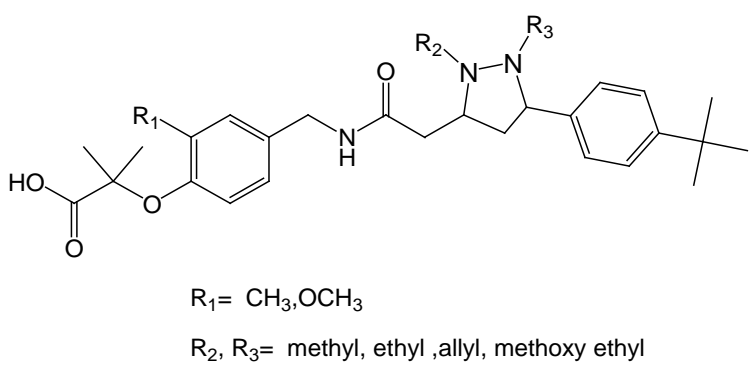

Fig. 28

\section{CONFLICT OF INTERESTS}

Declared none

\section{REFERENCES}

1. Huang WC, Chen Y, Nai-Wen Kan, Chun-Sheng Ho, Li Wei, Ching-Hung Chan, et al. Hypolipidemic effects and safety of lactobacillus reuteri 263 in a hamster model of hyperlipidemia. Nutrients 2015;7:3767-82. 
2. Santosh NM, Manjusha CN, Nikhil SS, Pritam ND, Vishakha RS, Swati AB. Synthesis and in vivo hypolipidemic activity of some novel substituted phenyl isoxazol phenoxy acetic acid derivatives. Bioorg Med Chem Lett 2014;24:2155-8.

3. Santosh NM, Priyanka TS, Devanand BS. Synthesis and hypolipidemic activity of novel 2-(4-(2-substituted aminothiazole-4-yl) phenoxy) acetic acid derivatives. Eur J Med Chem 2010;45:3096-100.

4. Li W, Hao-yan J, Xin-hua H, Wei-guo S, Bo-hua Z. Novel phenoxy alkyl carboxylic acid derivatives as hypolipidaemic agents. J Enzyme Inhib Med Chem 2012;27:311-8.

5. Turan-Zitouni G, Yurttas L, Kaplancıklı ZA. Synthesis and antinociceptive, anti-inflammatory activities of new aroyl propionic acid derivatives including $\mathrm{N}$-acylhydrazone motif. Med Chem Res 2015;24:2406-16.

6. Ghelardini C, Galeotti N, Gualtieri F, Scapecchi S, Bartolini A. 3$\alpha$-Tropanyl 2-(4-Cl-phenoxy)butyrate (SM 21): a review of the pharmacological profile of a novel enhancer of cholinergic transmission. CNS Drug Rev 1997;3:346-62.

7. Ghelardini C, Galeotti N, Gualtieri F, Scapecchi S, Bartolini A. Pharmacological characterization of the novel ACh releaser $\alpha$ Tropanyl 2-(4-bromophenyl) propionate (PG-9). CNS Drug Rev 2000;6:63-78.

8. Priyanka R, Dilipkumar P, Rahul RH, Hashim SR. Anticancer anti-inflammatory, and analgesic activities of synthesized 2(substituted phenoxy) acetamide derivatives. BioMed Res Int 2014. http://dx.doi.org/10.1155/2014/386473

9. Bhavna S, Pravin P, Hirva S. Chemical modification of paracetamol and their antimicrobial and pharmacological evaluation. Int J Res Pharm Biomed Sci 2014;3:12-31.

10. Anna Pratima GN, Dipali D, Hemant DU. Facile synthesis and in vivo hypoglycemic activity of novel 2, 4-thiazolidinedione derivatives. Eur J Exp Biol 2012;2:343-53.

11. Anna Pratima GN, Dipali D, Hemant DU. Facile synthesis and in vivo hypoglycemic activity of novel 2, 4-thiazolidinedione derivatives. Eur J Exp Biol 2012;2:1302-4.

12. Shahar Yar M, Afroz Bakht M, Siddiqui AA, Abdullah MM, Clercq ED. Synthesis and evaluation of in vitro antiviral activity of novel phenoxy acetic acid derivatives. J Enzyme Inhib Med Chem 2009;24:876-82.

13. Vinayak A, Sudha M, Lalita SK, Prakash KR. Novel substituted phenoxy derivatives of 2-Chloro-N-\{5-[2-(4-methoxy-phenyl)pyridin-3-yl]-[1,3, 4] thiadiazol-2-yl\}-acetamides: Synthesis, characterization and in vitro anticancer properties. J Pharm Chem Biol Sci 2014;2:130-7.

14. Lee K, Lee JH, Boovanahalli SK, Jin Y, Lee M, Jin X, et al. (Aryloxy acetylamino) benzoic acid analogues: a new class of hypoxiainducible factor-1 inhibitors. J Med Chem 2007;50:1675-84.

15. Pattan SR, Hullolikar RL, Pattan IS, Kapadnis BP, Dighe NS Dengale SS. Synthesis and evaluation of some new pyrazolo phenoxy acetic acid derivatves for their antitubercular activity. J Pharm Sci Res 2009;1:63-8.

16. Wei Ang, Yan-Ni L, Tao Yang, Jian-Zhong Y, Wei-Yi Pi, Ying-Hong Y. Synthesis and biological evaluation of 2-(3-fluoro-4-nitro phenoxy)-n-phenylacetamide derivatives as novel potential affordable antitubercular agents. Molecules 2012;17:2248-58.

17. Rajiv D, Devender P, Sunita B. Synthesis and biological evaluation of a novel series of 2-(2'-isopropyl-5'- methylphenoxy) acetylamino acids and dipeptides. Bull Chem Soc Ethiop 2006;20:235-45.

18. Amjid I, Hamid LS, Ashraf CM, Ahmad M, Weaver GW. Synthesis, characterization and antibacterial activity of azomethine derivatives derived from 2-formylphenoxyacetic acid. Molecules 2007;12:245-54

19. Kaplancikli ZA, Yurttas L, Turan-Zitouni G, Ozdemir A, Ozic R, Ulusoylar-Yıldırım S. Synthesis, antimicrobial activity and cytotoxicity of some new carbazole derivatives. J Enzyme Inhib Med Chem 2012;27:868-74.

20. Lee K, Hee Roh S, Xia Y, Kang KW. Synthesis and biological evaluation of phenoxy-n-phenylacetamide derivatives as novel pglycoprotein inhibitors. Bull Korean Chem Soc 2011;32:3666-74.

21. Takeda Y, Kawagoe K, Yokomizo A, Yokomizo Y, Hosokami T, Shimoto $Y$, et al. Synthesis of phenoxy acetic acid derivatives as highly potent antagonists of Gastrin/Cholecystokinin-B receptors. Chem Pharm Bull 1999;47:755-71.

22. Deepa P, Sen DJ. Synthesis and biological screening of some pyridazine derivatives. Int J Pharm Res Bio-Sci 2014;3:760-9.

23. Prashanth $T$, Lakshmi Ranganatha $V$, Naveen $P$, Gurupadaswamy HD, Bushra Begum A, et al. Synthesis of (4benzoyl-phenoxy)-acetic acid derivatives and their efficacy as antioxidant agents. Free Radicals Antioxid 2013;3:S50-S54.

24. Nkurunziza JB, Balakrishna K. Synthesis, characterization and antioxidant evaluation of a novel series of chalcone derivatives bearing 2-hydroxyquinoline moiety. Der Pharm Chem 2016;8:167-72.

25. Kuo-Yi Chen, Chin-Teh Huang. Investigation of the synthesis of phenoxy propionic acid derivatives based on 1, 3, 5-Triazine system. Int J Appl Sci Eng Res 2004;2:286-94.

26. Shao-Yong K, Si-Jia Xue. Synthesis and herbicidal activity of $\mathrm{N}$ (o-fluoro phenoxy acetyl) thioureas derivatives and related fused heterocyclic compounds. Arkivoc 2006;10:63-8.

27. Ramalakshmi N, Nirmalan NK. Synthesis of novel phenoxyisobutyric acid derivatives of choline and some of its salt. Int J ChemTech Res 2015;8:14-8.

28. Ioana MCI, Iuliana MP, Mariana NS, Adina C, Cristian T, Ionel B. Synthesis and characterization of some new 5-bromo-2-hydroxybenzamide derivatives. Rev Roum Chim 2015;60:615-8.

29. Hariprasath K, Umamaheswari P, Wicket SD. Hormone-based therapy in type 2 diabetes mellitus. Asian J Pharm Clin Res 2013;6:1-5

30. Gayathri GA, Gayathri M. Review on the enhancement of glucose uptake and Up-regulation of glucose transporters by antidiabetic medicinal plants. Asian J Pharm Clin Res 2016;9:2455-3891.

31. Manorama G. Impact of meal replacement on the health status of type II diabetes. Int J Curr Pharm Res 2014;6:79-82.

32. Sivakumar R, Lokesh N, Rajashekhar A, Ramu N, Saikishore P, Venkatanarayanan R. Docking studies on PPAR $\gamma$ of novel $\alpha-$ phenoxy phenyl propionic acid derivatives as antidiabetic agents. Der Pharm Sin 2011;2:327-32.

33. Paul M, Nicolas F, Alain L, Olivier P, Marie HF, Florent P, et al. The discovery of equipotent PPAR $\alpha / \gamma$ dual activators. Bioorg Med Chem Lett 2008;18:6251-4.

\section{How to cite this article}

- $\quad$ Shaheen Begum, Bharathi K, Prasad KVSRG. Mini review on the therapeutic profile of phenoxy acids and their derivatives. Int J Pharm Pharm Sci 2016;8(10):66-71. 